\title{
Profiles: Raymond S. Koff, MD
}

\author{
Raymond S. Koff ${ }^{1}$
}

Published online: 24 October 2016

(C) Springer Science+Business Media New York 2016

\section{Beginnings}

I was born in 1939, a few months before the outbreak of World War II in Europe and 2 years after the premature death of George Gershwin in 1937. For obscure reasons, in my youth, George Gershwin became my hero, and I read everything I could about the Gershwin brothers. Perhaps my interest was attributable, at least in part, to my older brother, who was playing piano professionally in New York and New Jersey while in junior high school, high school, college, and medical school. After training in cardiology, he began to practice in Connecticut and continues to do so. He encouraged me both musically (I play the trumpet non-professionally) and professionally, as I too entered medicine.

I majored in psychology in college and planned to become a psychiatrist even before enrolling in the fourth graduating class of the new Albert Einstein College of Medicine, in 1958. After my clerkship in Medicine, my interest became focused on Internal Medicine. This was solidified by a superb subinternship at Goldwater Memorial Hospital on Welfare Island (now Roosevelt Island, NY) under the aegis of a legendary teacher and Professor of Medicine at the College of Physicians and Surgeons, Dr. David Seegal, who became my first medical mentor, and with whom I developed a long-lasting and warm relationship. I also owe a debt of gratitude to his

Nice Work If You Can Get It (George \& Ira Gershwin, 1937).

Raymond S. Koff

rkoff@comcast.net

1 University of Connecticut School of Medicine, 2420 Beacon St., Unit 402, Chestnut Hill, MA 02467-1463, USA
Goldwater colleague, Dr. Arthur Wertheim, who taught me how to perform a physical examination by asking me at each point of the exam what I was doing and for what was I searching. This process required three different patients, since it lasted for nearly $6 \mathrm{~h}$. I am sure this prompted my lifelong interest in teaching the physical examination to medical students.

\section{Training in Medicine, Epidemiology, and Gastroenterology}

My residency on the Ward Medical Service of Barnes Hospital in St. Louis was remarkable for the two men who served as Co-Chairs of the Department of Medicine, Carl Moore and Sol Sherry, both extraordinary investigators, clinicians, and teachers, and the two Chief Residents who oversaw my training, Robert Packman and Robert Utiger. When he moved to Boston, Dr. Utiger and I reconnected. Many years later, Dr. Sherry and I renewed our acquaintance when we served as speakers on our respective areas of interest on a national tour, and we remained in contact until his untimely death.

After my residency, I was privileged to serve as an Epidemic Intelligence Service Officer of the National Communicable Disease Center (later the Centers for Disease Control and Prevention, CDC) and assigned to study the epidemiology of viral hepatitis in Boston under the direction of another charismatic leader, and my second mentor, Thomas C. Chalmers. I joined an on-going study, interviewing hepatitis patients and controls in ten Boston teaching hospitals. Meetings with Tom were always stimulating since he had so many innovative ideas that he would "bounce off" me for my appreciation or criticism. Because we found an association between the ingestion of 
either raw or steamed mollusks with hepatitis (presumably hepatitis A) during a non-epidemic period, it was my idea to determine the internal temperature of clams during steaming, since it seemed possible that the temperature reached at shell-opening (when the clams were considered to be most delicious) was insufficient to inactivate the virus. And that was what we found. The manuscripts describing the epidemiology study and the internal temperature of steamed clams were both accepted by the New England Journal of Medicine without revision. I should mention that this (no revisions required) never happened again during my career, a disappointment I have learned to live with.

One other, unpublished, study with Tom remains fixed in my mind. He wondered if deep palpation of the liver during a physical examination could elevate serum aminotransferase levels, somewhat analogously to the elevation of serum acid phosphatase levels after prostatic massage. In the study we designed, he would enter a patient's room, obtain oral permission, and then either deeply palpate the liver or not. In both instances, he would ask the patients to scream as if in pain. I waited outside each room with the door closed and would then dash in to get a blood sample. No, the enzymes were unaffected by palpation. During my stint with Tom, he introduced me to many of the leaders of gastroenterology, hepatology, and hepatitis research including Franz Ingelfinger, Kurt Isselbacher, Hy Zimmerman, Mort Grossman, Fred Kern, Saul Krugman, Wolf Szmuness, Robert McCollum, Marv Sleisenger, Allan Redeker, John Galambos, Burt Combes, Charlie Davidson, Lionel Bernstein, and several others. Each of them were very kind to me and supportive. I joined the Ingelfinger Journal Club, which met regularly at Boston University and included such stellar participants as Don Small, Jerry Trier, Roger Lester, and Norm Grace. I was fascinated with hepatology and in particular hepatitis research and decided to continue my training with Kurt Isselbacher at the Gastrointestinal (GI) Unit of the Massachusetts General Hospital (MGH). The training was superb, but my interest in the GI tract and endoscopy was limited and has remained so. In fact, I am probably one of the few GI trainees who over the course of his lifetime has had more endoscopies performed on himself than he performed. My fellow trainees were remarkable individuals from whom I learned much and who became leaders of academic medicine, including Robert Glickman, Robert Ockner, Gil Thompson, Neil McIntyre, Jim McManus, Bud Tennant, and Elliot Alpert. Seymour Sabesin, one of the junior faculty, and I collaborated on a number of research and teaching projects for many years thereafter.

\section{Hospital and Academic Positions}

Although Kurt was kind enough to offer me a faculty position when I had completed my training with him, I opted for a position as a Clinical Investigator at the Boston Veterans Administration (VA) Hospital, where the extraordinary hepatologist Hy Zimmerman was Chief of Medicine and there were more liver fellows than GI fellows. Working with Hy and Jack Patek, another pioneer in liver disease research, whom I first met when he was an attending physician at Goldwater Memorial, was an exhilarating experience, and my laboratory and clinical research was productive. I was fortunate to spend several months on a mini-sabbatical studying galactosamine hepatotoxicity in tissue culture with Arie Zuckerman at the London School of Hygiene and Tropical Medicine. Hy decided to return to Washington DC about a year or two later, but he and I maintained a close relationship thereafter, including participation in VA Cooperative Trials. My great colleague and friend at the VA, Elihu Schimmel, became the Chief of GI, and first Jack Patek and then I became Chief of Hepatology, both at the VA and at Boston University School of Medicine. Our combined, integrated program was a largely clinical one, highly sought after, and our strong faculty was bolstered by weekly teaching sessions with many of Boston's outstanding gastroenterologists, including Franz Ingelfinger, Jerry Trier, Roger Lester, Herbert Cooper, Joel Solomon, and later, Win Arias. Elihu was the cement that held the program together for several decades. He is a brilliant clinician-educator, with an adamantine curiosity for all things of science, an interest in word origins, a Talmudic scholar, and a first-rate mentor to fellows and faculty. Among the many academicians who were touched by Elihu and our training program were Stu Spechler, Ward Olson, Roberto Grozmann, Ralph Gianella, Greg Eastwood, and Sanjiv Chopra, among others.

My years at the VA contributed greatly to my intellectual and academic growth. I began participating in clinical trials, contributed chapters to multiple textbooks, wrote a few books on liver disease and edited several others, and served on the Epidemiology and Disease Control Study Section of the NIH, and later as a consultant to the Food and Drug Administration (FDA).

I was fortunate to receive an award from the American College of Physicians that permitted me to attend the renowned liver biopsy review sessions with Hy Zimmerman and Kamal Ishak at the Armed Forces Institute of Pathology in Washington for a full year. Also, during this time, Lionel Bernstein, at the National Library of Medicine, invited me to join a prestigious panel working on what became known as the Hepatitis Knowledge Base. I 
later became the leader of that effort and received support from the New England Journal of Medicine. Unfortunately, the project was ahead of its time and ultimately ended.

Also during this period, I rose from Assistant Professor to Professor of Medicine at Boston University, became Chair of the Division of Medicine's Promotion and Appointments Committee, and later served on the Dean's Committee on Promotions and Appointments.

\section{The Move West}

After 17 years at the VA, I decided to seek a change in venue. Over the years, I had spoken several times at Boston University's community teaching hospital in Framingham (Framingham Union Hospital), about 15 miles west of Boston, and was impressed by the quality of the staff and the association with the Framingham Heart Study. When the Chief of Medicine, Isadore Rosenberg, a world renowned thyroid researcher, stepped down, I was appointed to succeed him. These were exciting and productive years, with the business of medicine taking front stage after the introduction of diagnostic-related groups (DRGs); our efforts to improve recruiting of Internal Medicine house staff, providing a training site for medicine residents from Boston University, then from the Beth Israel Hospital and the University of Massachusetts (UMass); our introduction of Physician Assistant Training from Northeastern University; our merging with a non-teaching hospital in nearby Natick to form the MetroWest Medical Center; and eventually the sale of both hospitals to a succession of for-profit healthcare systems. I was smart enough when $\mathrm{I}$ arrived in Framingham to appoint as Director of the Residency Program a young, brilliant infectious disease colleague, Thomas Treadwell, who continues in that role today, beloved by generations of house officers. I also recruited a great personal assistant, Janet Smith, who "ran" the Department of Medicine, served as my receptionist, and did my billing.

I was fortunate that I had the freedom to maintain a clinical practice in hepatology and had hired a remarkable nurse, Maureen Cormier, who became the best research and clinical assistant I have ever encountered. Maureen was careful, studious, congenial, and adored by my patients and trial participants. Our "dropout" rates in our clinical trials were remarkably low. Because I was not dependent on my practice income, appointments for new patients were usually scheduled for at least an hour but could be longer, and follow-ups were as long as I felt necessary. Unfortunately, in recent years, such an approach has been deemed cost-ineffective.

Just before I arrived in Framingham, I joined the Clinical Teaching Project (CTP) Committee of the American
Gastroenterological Association (AGA), under the direction of David Sachar, whom I succeeded as Chairman. My association with the CTP was another stimulating experience, including working with Dave Alpers, whom I knew from my days at the MGH and who now directed the Undergraduate Teaching Project. Among the team of contributors to the CTP were Doug Drossman, the late Caroline Riely, Stu Spechler (who had been a medical student, resident, fellow, and junior faculty member at the Boston VA), Peter Green, Joe Sweeting, Mort Burrell, Mark Peppercorn, Santiago Vera, Jules Dienstag, and several others. We had enormous fun and produced a number of slide sets for self-study and lecturers that received considerable acclaim from the GI community and went through several revisions.

My tenure as Chief of Medicine at MetroWest, which was among the longest among Chiefs appointed at the same time at similar institutions in Eastern Massachusetts, was marked by exhilaration during the first 5 years of my administration, slightly less contentment during the second 5 years, and some vexation during the last three, when the for-profit owners were threatening, unsuccessfully, to abandon the teaching program. However, the strong support of the faculty and community physicians stymied that threat.

With the support of Herb Bonkovsky, with whom I had started working on the Hepatitis C Antiviral Long-term Treatment against Cirrhosis (HALT-C) trial while I was still in Framingham, I decided to leave MetroWest and join his staff at the UMass GI Division. Maureen Cormier and Janet Smith came with me. I became Director of Clinical Hepatology Research and Professor of Medicine, and we participated in a large number of clinical trials of treatment for hepatitis $\mathrm{C}$ and $\mathrm{B}$.

\section{Joining Industry}

While my clinical practice was expanding at UMass, and we were participating in several trials, Roche Pharmaceuticals offered me a position that would allow me to continue in my role as an educator, work from my home, and provide advice on their current and future hepatitis treatments. And it enabled me to continue to speak to large and small groups, including hepatology thought leaders, insurance companies, pharmacy benefit managers, and colleagues across the country. Although my area of coverage was supposed to be New England, I soon found myself lecturing in Minneapolis, San Diego, and St. Louis, to name a few. I pointed out to my Swiss colleagues at Roche, who seemed unfamiliar with U.S. geography, that New England was small with just six states but that I would be willing to cover the original 13 colonies. They laughed, 
and I continued to travel widely. I was also given a role in the assessment and awarding of investigator-initiated research funding which I found to be a stimulating opportunity to help both young and seasoned investigators improve their grant applications. After an administrative change at Roche, investigator-initiated research was dismantled, and the work environment was no longer tolerable to me. Fortunately, Herb Bonkovsky, having left UMass for the University of Connecticut (UConn), invited me to join the UConn faculty. I became a Clinical Professor of Medicine in 2003 and have maintained that title since.

\section{Life After Industry}

Although I gave up my position at Roche after 3 years, the company and a number of other pharmaceutical companies asked me to serve as a speaker, and I traveled extensively throughout the USA. This ended several years later when the companies mandated that I use only their FDA-approved slides, which were poorly designed and largely verbatim recitations of the product information material. Because I was unwilling to use what I considered to be inferior and ineffective teaching aids, I stopped speaking for commercial entities.

I have had the good fortune to serve as faculty for Bill Steinberg's GI Board Review Course for a number of years, lecturing on acute and chronic viral hepatitis, autoimmune hepatitis, and acute liver failure. One of the most pleasing aspects of this has been the experience of arriving at a lecture site in a small city and learning that one or more members of the audience remembered my lectures from the course (and incidentally passed the Board Examination on the first try).

I have also served as faculty on Bill's Practical Reviews of Gastroenterology, abstracting and critiquing published liver papers and making MP3s for distribution. I continue to do this today. It allows me to select material that is new, innovative, and likely to be important to practitioners and that helps expand my own knowledge base. To do this, I review a number of selected journals each month.

I have served on the Editorial Boards of Gastroenterology, the American Journal of Gastroenterology, and Digestive Diseases and Sciences and as an Associate Editor and Book Review Editor of Hepatology. One of my most pleasing current activities is serving as a referee for a number of digestive disease journals. Although I restrict what I review to areas that I have some knowledge about and find most interesting, the benefit of careful assessment of new research for both the authors and the assessors is, I hope, worthy of the effort.

\section{Summary}

As I look back, I believe I was fortunate to have had a career that involved the care of patients, multiple research opportunities, and rewarding roles as an educator and administrator. I owe much to the kindness of the mentors and colleagues who encouraged and supported me. I also am extremely grateful for the love and support of my wife, Elissa, who consistently inspires me by her brilliance, uncommonly good sense, and personal scholarship.

During my lifetime, hepatology has moved from a more or less cognitive diagnostic discipline to a dynamic one resulting from the development of hepatitis vaccines, new therapies, lifesaving liver transplantation, and more optimal management of chronic liver disease. Nonetheless, much remains to be done, and a career in hepatology remains an exciting and rewarding prospect for those looking for "nice work." 